\title{
THE TOURISM POTENTIAL OF THE COUNTIES LOCATED IN THE KUYAVIA-POMERANIA AND POMERANIA PROVINCES IN RESPECT OF WATERWAYS REVITALISATION
}

\author{
AliCJA GONiA, ${ }^{1}$ HANNA MICHNIEWICZ-ANKIERSZTAJN, ${ }^{2}$ \\ ANNA DŁUŻEWSKA ${ }^{3}$
}

Kazimierz Wielki University in Bydgoszcz, POLAND

${ }^{1}$ e-mail: alicja.gonia@ukw.edu.pl

2 e-mail: hanka@ukw.edu.pl

${ }^{3}$ e-mail: dluzewska.a@gmail.com

KEYWORDS | Vistula river, tourism, International Waterway E70

ABSTRACT The aim of the paper is to depict the tourism potential of the communes located in the vicinity of the River Vistula (in the Kuyavia-Pomerania and Pomerania Provinces), to perceive that potential as a major factor in socio-economic activation of the region, and finally to study the impact of the Vistula revitalization on the development of tourism especially in relation to the improvement of tourist-centred applications. It can be assumed that the depicted region possesses the necessary potential, both natural and cultural, to develop various types and forms of tourism. Still, this development is conditioned by the current state of tourist-centred preparations and local economy, especially in relation to expenditure on tourism. In addition, one can suppose that the development of tourism will be supported by fulfilling the tasks aimed at the revitalisation of the lower course of the River Vistula, mainly focusing on the E70 waterway fragment. The analysis of the socioeconomic situation together with the tourism potential in the studied region has been enabled by the statistical data provided by the Local Data Bank of the Central Statistical Office (Bank Danych Lokalnych GUS), and by finding documents and analysis relating to the revitalisation of inland waterways in Poland. The collected data refers to 2013.

\section{Introduction}

After years of neglect, the River Vistula gained in importance and is finally noticed by entrepreneurs and academics of various fields. This is caused by the discovery of the river's untapped potential. A great change of perspective has been brought by the integration of Poland with the European Union, where waterways are fully utilized for both economy and tourism. It can be claimed that the River Vistula is a unique waterway. Unlike most other European rivers, it has 
not been strongly affected by regulations. As a result, many habitats and nesting grounds for both fauna and flora can be found in its vicinity. ${ }^{1}$ It functions as an international ecological corridor, and, in consequence, most of it is included in the Natura 2000 network. In effect, it is postulated that any human activity related to the River Vistula should always take into account the primacy of the natural environment. ${ }^{2}$ It seems to be similar to the principle of ecological river management introduced in the mid 1990s. ${ }^{3}$

At the same time, the River Vistula functions as an essential element of inland waterways in respect of tourism and economy: International Waterway E70 connecting West Europe (Antwerp) with East Europe (Klaipeda), and International Waterway E40 joining the Baltic Sea (Gdańsk) with the Black Sea (Odessa). A more conscious approach to the utilization of those routes for both tourism and transportation could become an impulse in developing nearby communes, regions, and consequently, the whole country. This process is hindered by a prolonged neglect of infrastructure and of adaptations preparing the river for transportation of goods. As a result, the River Vistula is classified as a regional and unfavourable shipping route of: Ia, Ib, II, and III classes. The stretches of the river adequate for those purposes, and hence deemed as international shipping routes (classes: IV, Va, and Vb), constitute barely $100 \mathrm{~km}$. These sections can be found between the estuary of the River Przemsza and the Łączyński Canal, between Płock and Włocławek, and also the Martwa Wisła near Gdańsk. ${ }^{4}$ The classification referred to here is based on types of ships which can safely travel down the waterways. It also reflects the minimal size of those shipping routes and encountered water gates, spans of bridge pillars, pipelines, and other obstacles interfering with the river (cf. Inland Waterways Bill from 2013). ${ }^{5}$

Adjusting the Vistula routes to the optimal norms adequate for inland waterway transportation (class IV and higher) requires serious investments, e.g., constructing dams and barrages. ${ }^{6}$ It is estimated that at present waterways can be reconstructed to their 1940s state, when they belonged

${ }^{1}$ J. Angiel, Rzeka Wisła, jej wartości i percepcja. Wisła w edukacji geograficznej, Uniwersytet Warszawski, Wydział Geografii i Studiów Regionalnych, Warszawa 2011, p. 55; G. Leśniewski (ed), Wisła dzika rzeka, Lubelskie Towarzystwo Ornitologiczne, Wydawnictwo Epigraf, Warszawa 2012, p. 8; I. Sulimowicz, Wykorzystanie dolin rzecznych Bydgosko-Toruńskiego Obszaru Metropolitalnego dla potrzeb rozwoju turystyki i rekreacji, in: Warunki rozwoju turystyki $w$ dolinach rzecznych, ed. M. Grabiszewski, Zeszyty Naukowe WSG, t. 15, nr 7, Wydawnictwo Uczelniane WSG, Bydgoszcz 2010, p. 60.

2 J. Owsiak, J. Sewerniak, Ekorozwój a turystyka na przykładzie dorzecza Drwęcy, in: Rola samorządu terytorialnego w kształtowaniu przestrzeni obszarów chronionych, Ekologia w turystyce. Materiały konferencyjne, Włocławskie Centrum Edukacji Ekologicznej, Włocławek 2001, p. 57.

${ }^{3}$ R. Barrakud, Rivieres du futur, wild rivers?, eds. D. Féménias, O. Sirost, «Fleuves, estuaires et cours d'eau: représentations et pratiques», VertigO, hors-série 10/Décembre, https://vertigo.revues.org/11411?lang=eng\#bibliography.

${ }^{4}$ D. Rozkrut, Żegluga śródlądowa w Polsce w latach 2006-2009, GUS Urząd Statystyczny w Szczecinie, Warszawa 2010, pp. 18-19, www.stat.gov.pl.

${ }^{5}$ Ustawa o żegludze śródlądowej z dnia 21 grudnia 2000 r., Dziennik Ustaw Rzeczypospolitej Polskiej z dnia 6 grudnia 2013 r. poz. 1458, Obwieszczenie Marszałka Sejmu Rzeczypospolitej Polskiej z dnia 15 października 2013 r. w sprawie ogłoszenia jednolitego tekstu ustawy o żegludze śródlądowej.

${ }^{6}$ Z. Brenda, Dolna Wisła - droga wodna, obszar aktywizacji gospodarczej województwa kujawsko-pomorskiego, „Gospodarka Wodna, 2013, nr 6, pp. 213-216. 
to class III. ${ }^{7}$ Currently those sections of the River Vistula which can boast class II, can be accessed by small crafts with draught below $50 \mathrm{~cm}$, by small boats for tourists, and by kayaks, ${ }^{8}$ and even that only when the water level is satisfactorily high. However, it can be claimed that what is inadequate to transport is more than appreciated by water tourism and riverside tourism. Such a claim is supported by the fact that both the river and its valley retained their features, which make them spellbinding from the perspective of tourists. It must be mentioned here that Poland has not signed the European Agreement on Main Inland Waterways of International Importance (AGN) due to the lack of a possibility to conform with European standards. As a result, undertaken tasks are limited to maintaining and modernising present tourism-centred waterways in relation to the registry of heritage. ${ }^{9}$ Z Sulimowicz supports this view when reflecting that in order to cope with EU trends, with stimulating the development of waterways, but also bearing in mind the need to protect and promote the largest European natural resort found in Poland, it seems most reasonable to adopt the mentioned waterways for the purpose of tourism and recreation. ${ }^{10}$

Moreover, tourism should positively impact on the development of waterways and river transport, and it can spark the development of lands found in the vicinity of rivers. Tourism seems to be the only rational chance to maintain the traffic on Polish waterways. ${ }^{11}$ The example of the River Vistula is most prominent as in relation to proposed international routes only the E70 waterway can be adopted for the purpose of tourism at the Northern part of the River Vistula. ${ }^{12}$ In recent years, various activities aimed at the utilization of tourist potential of the basin and the lower course of the River Vistula. Improving transportation and developing different forms of tourism became focal points. The promotion of the E70 waterway had a considerable impact on the situation, resulting from the 2009 document signed by six Councillors (West Pomerania, Lubusz, Great Poland, Kujawy-Pomerania, Pomerania, and Warmia-Mazovia) entitled "Preparations for the spatial policy of the revitalisation of inland East-to-West waterway encompassing Oder, Warta, Noteć, Bydgoszcz Canal, Vistula, Nogat, Szkarpowa, and the Vistula Lagoon (plans for the Polish stretch of the E70 waterway)". Among other goals, the joint efforts are supposed to lead towards supporting initiatives aiming at the activation of water tourism on the E70 waterway by making the most of its cultural and natural resources. Secondly, these should allow starting initiatives aimed at

7 T. Jarzębińska, Rola polskich dróg wodnych śródlądowych w sieci europejskiej, in: Rewitalizacja drogi wodnej Wisła-Odra szansą dla gospodarki regionu, t. I, Przyroda i turystyka regionu Pomorza i Kujaw, ed. Z. Babiński Urząd Marszałkowski Województwa Kujawsko-Pomorskiego, Instytut Geografii UKW, Bydgoszcz 2008, p. 15; R. Zamyślewski, Wista. Album map dla wodniaków. Przewodnik po polskich drogach wodnych, Stowarzyszenie na rzecz turystyki aktywnej, rekreacji i wypoczynku ,Szkoła Przygody”, Bydgoszcz 2011, p. 61.

${ }^{8}$ Z. Brenda, op.cit.

9 T. Jarzębińska, op.cit., p. 18.

${ }^{10}$ I. Sulimowicz, op.cit., p. 64.

11 T. Jarzębińska, op.cit., p. 15; W. Łożewski, Partnerstwo w rozwoju dróg wodnych. Miejsce żeglugi towarowej $w$ planach rewitalizacji drogi wodnej Wisła-Odra, in: Rewitalizacja drogi wodnej Wisła-Odra szansa dla gospodarki regionu, t. III, Przyroda i turystyka regionu Pomorza i Kujaw, ed. Z. Babiński, Urząd Marszałkowski Województwa Kujawsko-Pomorskiego, Instytut Geografii UKW, Bydgoszcz 2009, p. 176; R. Wasil, Rewitalizacja szlaków wodnych Delty Wisty i Zalewu Wiślanego, in: Rewitalizacja drogi wodnej..., t. I, p. 61.

12 T. Jarzębińska, op.cit., p. 15. 
the ratification of the European Agreement on Main Inland Waterways of International Importance (AGN) as in due course it would commit the government to adapting Polish waterways to European standards. ${ }^{13}$

\section{Methodology and Scope of Research}

In the light of the abovementioned issues, this paper's aim is to depict the tourism potential of communes located in the vicinity of the River Vistula, to perceive that potential as a major factor in socio-economic activation of the region, and finally to study the impact of Vistula revitalization on the development of tourism especially in relation to the improvement of tourist-centred applications. As a result of a specific nature of the river, namely due to its diversified hydrological, landscape, and economic features, the presented analysis will be spatially limited to the lower course of the River Vistula found in the Kujawy-Pomerania and the Pomerania Provinces (first order of administrative regions in Poland, equivalent to counties or provinces in many countries). Owing to the previous actions as well as to cultural and anthropogenic qualities, this region is believed to be predisposed towards the development of tourism and recreation.

The contemporary utilisation of the lower course of the River Vistula both for tourism and transportation is rather limited, however, is can be assumed that the depicted region possesses the necessary potential, both natural and cultural, to develop various types and forms of tourism. Still, this development is conditioned by the current state of tourist-centred preparations and local economy, especially in relation to expenditure on tourism. In addition, one can suppose that the development of tourism will be supported by fulfilling the tasks aimed at the revitalisation of the lower course of the River Vistula, mainly focusing on the E70 waterway fragment.

For the purpose of the presented study, the lower course of the River Vistula is not understood as a physical-geographical region stretching from Fordon in Bydgoszcz up to Żuławy, despite the fact that this is consistent with the widespread division of Poland into physical-geographical regions. ${ }^{14}$ Instead, the span of the river from Narew to Żuławy is taken under the consideration. The following analysis relates to 54 selected riverside communes, out of which 37 are rural in nature and 17 are urban. Also largest towns and cities are studied due to their placement at the lower course of the river: Toruń, Bydgoszcz, and Gdańsk. As a result of the incomplete data found at the Regional Data Bank (Bank Danych Regionalnych), the analysis does not take into account the rural and urban communes of Sztum. The analysis of the socio-economic situation together with the tourism potential in the studied region has been enabled by the statistical data provided by the Local Data Bank of the Central Statistical Office (Bank Danych Lokalnych GUS), and by finding documents and analysis relating to the revitalisation of inland waterways in Poland. The collected data refers to the year 2013 .

\footnotetext{
13 www.mdwe70.pl.

14 J. Kondracki, Geografia Polski. Mezoregiony fizyczno-geograficzne, PWN, Warszawa 1994.
} 
It is possible to assess the tourism potential as a collection of factors influencing the capacity to develop tourism at a given location ${ }^{15}$ as a result of creating a comprehensive database for urban, rural-urban, and rural communes found near the River Vistula. After analysing the variables described in the Regional Data Bank, ${ }^{16} 29$ features reflecting tourism potential have been selected and divided into three groups: tourism qualities, tourism development, and tourist traffic. ${ }^{17}$

In order to capture similarities in the tourism potential of respective communes, it is necessary to resort to applying multivariable calculus in order to analyse $k$-means clustering, as well as calculating the Euclidean distance for each administrative unit, which has been preceded by data standardisation. The initial results of $k$-means clustering, in relation to the data obtained from the database, have indicated that a substantial discrepancy between cities and the rest of communes assigned to other clusters, and, consequently, it seems justifiable to divide and re-calculate the results separately for urban and for rural areas. Such an approach is supported by the studies published jointly by Prof. S. Liszewski "Możliwości i kierunki rozwoju turystyki w Dolinie Odry" ("Possibilities for and Directions of Tourism Development in the Oder Valley") (see page 13). ${ }^{18}$

The authors have also attempted to classify communes in respect of their current natural and cultural potential, tourism infrastructure as well as expenditures on and income from tourism. Secondly, they verified to what extent the current state of the tourist-centred preparations of the River Vistula enable the development of water tourism in the studied communes.

\section{Tourism Function of Towns and Cities Located at the Rivep Vistula}

In order to assess the tourism relevance of communes found in the vicinity of the River Vistula, the authors have established tourism functions for each commune. This function is understood here as "all socio-economic activities in a location or region focusing on tourist services, which indicate the local capacity for fulfilling specific tourist needs." ${ }^{19}$ Hence, tourism function depicts the level of tourism development of a commune, which in turn reflects a general socio-economic status. It is possible to perceive a developing tourism function of a location when the Baretje and Defert indicator reaches the value of 100 , or in other words when the volume of accommodation for tourists equals the volume of local inhabitants. ${ }^{20}$ The analysis of those indicators in the Kujawy-Pomerania and the Pomerania Provinces demonstrates that there is not a single commune, town or city with a primary tourist function. The highest Baretje and Defert indicators, reflecting the development

${ }^{15}$ A. Zajadacz, J. Śniadek, Ocena potencjału turystycznego, in: Uwarunkowania i plany rozwoju turystyki, eds. Z. Młynarczyk, A. Zajadacz, t. III, Walory i atrakcje turystyczne. Potencjał turystyczny. Plany rozwoju turystyki, Wydawnictwo Naukowe UAM, Poznań 2009, pp. 35-58.

16 www.stat.gov.pl/bdl (15.09.2014).

17 J. Kaczmarek, A. Stasiak, B. Włodarczyk, Produkt turystyczny, PWE, Warszawa 2005, p. 52; A. Zajadacz, Potencjat miast na przykładzie wybranych miast Sudetów Zachodnich, Bogucki Wydawnictwo Naukowe, Poznań 2004, p. 40 after L. Butowski 1996.

18 S. Liszewski (ed), Możliwości i kierunki rozwoju turystyki w Dolinie Odry, Katedra Geografii Miast i Turyzmu, Łódzkie Towarzystwo Naukowe, Łódź 2003, p. 13.

19 Z. Kurek (ed), Turystyka, PWN, Warszawa 2007, p. 40.

20 J. Warszyńska, A. Jackowski, Podstawy geografii turyzmu, PWN, Warszawa 1979, p. 67. 
of tourism function, have been found for Ciechocinek (46) and the coastal commune of Stegna (54.4). For the rest of locations, the indicator is drastically lower: 5.4 (Gniew), 2.8 (Gdańsk), around 1.5 (Toruń and Grudziądz), and lower for other places. In 23 communes the indicator equals zero.

The highest density of the accommodation measured as a number of accommodations per square kilometre has been found in Ciechocinek (330.6), and among rural communes in Stegna (31.8). In urban locations the density of accommodations reaches the following levels: 55 (Gniew), 50 (Gdańsk), 40 (Pelplin), 25 (Toruń), 20 (Kwidzyn), and between 10 and 20 (Nowe, Bydgoszcz, Grudziądz, Chełmno). Other towns can boast of the indicator below 10 (Tczew, Solec Kujawski, Włocławek), while rural communes note the decrease to 1 and below.

The domination of Ciechocinek (value of 7,259) has also been confirmed by the tourist traffic density indicator (Defert) demonstrating the number of tourists taking advantage of accommodations per $1 \mathrm{~km}^{2}$. This indicator appears as much higher especially in locations with a significant density of accommodations: Gniew and Gdańsk (around 2,400), and Toruń (slightly above 2,100). Still, there are some locations without a positive correlation between the density of accommodations and tourist traffic indicator, e.g., Pelplin and Stegna, while in others the situation is the exact opposite, e.g., Chełmno, Tczew, and Nowe. Finally, Schneider's indicator, which reveals the relation between tourists staying overnight and the population of local inhabitants, is most prominent for Ciechocinek again, and for Stegna, Gdańsk, and Gniew. The study of the tourist traffic based on the cluster analysis for all riverside communes suggests that Gdańsk, Bydgoszcz, Toruń, and Ciechocinek constitute a separate cluster due to much higher indicators: Charvet, Beretje and Defert, density of accommodation, and tourism income. The remaining urban and rural communes must be regarded as a distinct cluster, however, Stegna should receive special attention among those.

In terms of rural communes the following clusters have been differentiated: four clusters with two communes, and one cluster with 30 communes. The first of those belongs to Gniew and Nowe - accommodations catering for nearby castles found in major towns in those communes; the next cluster is Dragacz and Wielka Nieszawka - the highest number of hotel accommodations offered to Polish residents; the third is constituted by Osielsko and Tczew found near Bydgoszcz - significant numbers of Polish and foreign visitors; and finally. Stegna commune amounts to an independent cluster - it can boast a high number of tourist in comparison to other rural communes, which is mostly caused by the vicinity of Gdańsk Bay.

The analysis of the selected indicators demonstrated the primacy of Ciechocinek and Stegna in respect of tourist traffic along the Vistula River. Hence, two towns with a dominating spa function, one of which located at the Baltic Sea like the city of Gdańsk, the only other coastal commune under investigation. It may be concluded then that in the lower course of the Vistula River those communes which cannot boast a specific function are not important from the perspective of tourism. The low values of the presented indicators suggest that there is no well integrated tourism product which would encompass all or most of riverside communes. 


\section{Tourism Potential of Communes Located in the Lowep Course of the River Vistula}

In order to assess the tourism potential, a number of variables for 2013 have been selected from the Local Data Bank of the Central Statistical Office. These are supposed to ascertain the tourist-centred attractiveness of specified location in relation to: forest areas, protected areas, number of museums, number of museum goers, number of accommodations, and finally number of domestic and international tourists. R. Wiluś postulates that "the development of tourism on rivers depends on what is found in its vicinity, and the other way around. A waterway is not limited to the river itself, but also its surroundings perceived by the tourist.".21 Exactly for this reason, the presented analysis encompasses not only qualities, but also riverside management and the vicinity of the River Vistula. For the purpose of this study this closest area is understood as the riverside communes.

It is postulated here that the tourism attractiveness of riverside communes depends mostly on their qualities and then secondly on the development of tourism. ${ }^{22}$ In order to verify the suppositions relating to current tourism potential of the River Vistula and its possible applications, the authors decided to resort to multivariable analysis based on the agglomeration methods and $k$-means method. Both of those enabled the identification of cities and towns, and also of communes similar in respect of tourism development. The discussed analysis were conducted separately for urban and for rural locations. Taking into account natural and cultural qualities, e.g., valuable natural areas, monuments, and museums, the following urban and rural riverside clusters have been found:

- city of Gdańsk due to a significant number of monuments, museums, forest areas, and parks (cluster III),

- city of Bydgoszcz as a result of nearly 30\% forest coverage, above 6.000 hectares of protected areas, and a substantial amount of parks (cluster IV),

- nine communes (Bobrowniki, Cedry Wielkie, Czernikowo, Grudziądz, Kwidzyn, Osielsko, Solec Kujawski, Wielka Nieszawka, and Zławieś Wielka) due to high percentage of forest areas, e.g., above $80 \%$ in the communes of Solec Kujawski and Wielka Nieszawka (cluster I),

- rural communes (Chełmno, Dąbrowa Chełmińska, Dragacz, and Włocławek) as large parts of those are constituted by protected areas (cluster V).

Similarly, clustering allowed dividing rural communes into five groups in relation to potential constituted by tourism, natural, and cultural qualities:

- communes characterised by a large amount of forest areas (Solec Kujawski, Osielsko, Bobrowniki, Czernikowo, Obrowo, Sadlinki) as well as recreational parks (Tczew, Solec Kujawski) (cluster I),

- separate cluster constituted by a single commune of Wielka Nieszawka due to the highest percentage of forest areas (89\%) in the whole study (cluster IV),

${ }^{21}$ R. Wiluś, Od szlaku wodnego do nadrzecznego regionu turystycznego - kilka uwag o roli rzeki w kształtowaniu regionu turystycznego, in: Rewitalizacja drogi wodnej..., t. III, p. 51.

${ }^{22}$ A. Czarnecki, M. Luc, A. Lewandowska-Czarnecka, Waterway Contributions to Ecological European Tourism and Interregional Economy: Example of West-East Inland Route in Poland, "Journal of Agricultural, Food, and Environmental Sciences" 2007, Vol. 1, Issue 1, www.scientificjournals.org/journals2007/j_of_agri.htm. 
- communes with the highest share of protected areas (Chełmno, Dąbrowa Chełmińska, Dragacz, Włocławek) (cluster V),

- communes characterised by tourism and cultural qualities measured in the amount of monuments (Nowe, Stegna, Miłoradz) (cluster III),

- the remaining 22 communes with varied tourism qualities (cluster II).

Conducting the analysis of the development of tourism in the studied communes proves that the distribution is uneven and concentrated around towns and cities. On the basis of data obtained from the Local Data Bank (2013) it is estimated that Gdańsk was characterised with the highest amount of accommodation, namely 115. The remaining locations possess much fewer lodgings: Ciechocinek (39), Toruń (36), Bydgoszcz (25), Grudziądz, Kwidzyn and Włocławek (around 10 in each). Further away from cities and towns, accommodations are scattered and the access to lodgings is much more difficult. Only Stegna, with 68 accommodations, stands against the trend. The rest of communes usually boasts only a handful of places for tourists. Nearly half (43\%) of the studied communes does not posses a single registered accommodation. On top of that, it must be clarified that only a scarce group of accommodations caters for tourists travelling on waterways.

As a result of signing an agreement between Chief Executives from six provinces in respect to the development of the E70 waterway, new marinas and quay have been established in Bydgoszcz, Włocławek, and Tczew, and boulevards have been renovated in Włocławek, Toruń, Grudziądz, and Tczew. In addition, the part of the Bydgoszcz Canal, which has a pivotal function in linking the waterways linking the East with the West, has been revitalized together with the quay in the centre of the city, the Mill Island, rowing course at Brdyujście, and Plant found near the odl Bydgoszcz Canal (the result of the Reuris EU project). A new port and quay at Grudziądz have commenced, ${ }^{23}$ while the crest of the dam in Włocławek is already rebuilt ${ }^{24}$. Despite all those works in progress, the placement of tourism instrastructure is still uneven when looking at the whole length of the River Vistula. ${ }^{25}$ According to R. Zamyślewski, author of guides and maps for users of inland waterways ${ }^{26}$, the lack of the infrastructure for waterways travellers and for tourists is still significant (2011). Those which can be reached are usually newly built or renovated marinas, located in major cities and towns, e.g., Bydgoszcz, Toruń, Grudziądz, Włocławek, and Tczew. Consequently, there is not much that can be found in terms of smaller infrastructure, placed in smaller towns, which would enable safe mooring while sightseeing the neighbourhood.

One of the key factors influencing the development of tourism are tourist routes, which can be perceived as an element of tourism management. ${ }^{27}$ The studied stretch of the River Vistula

${ }^{23}$ P. Całbecki, Rzeki dla regionów - czy stać nas na projekty cywilizacyjne?, „Gospodarka Wodna” 2013, nr 6, p. 205.

24 „Many European cities are falling in with international trends, rediscovering their riverscapes and making use of their waterfront position as a way of distinguishing the attributes they have to offer as a location." Ch. Hölzer, T. Hundt, C. Lüke, O.G. Hamm, Riverscapes Designing Urban Embankments, Birkhaüser Basel, Boston, Berlin 2010, p. 24

25 J. Angiel, Rzeka Wisła, jej wartości i percepcja. Wisła w edukacji geograficznej, Uniwersytet Warszawski, Wydział Geografii i Studiów Regionalnych, Warszawa 2011, p. 65.

${ }^{26}$ R. Zamyślewski, Wisła..., p. 50.

${ }^{27}$ A. Kowalczyk, M. Derek, Zagospodarowanie turystyczne, Wydawnictwo Naukowe PWN, Warszawa 2010 , p. 36. 
possesses only one kayak route and one sailing route; however, there are many other kayak routes crossing or joining it: Brda, Noteć, Drwęca, Wda, Zgłowiączka, Osa, Liwa, Wierzyca, and Mątawa. Bydgoszcz Water Junction functions as an important node in the development of Polish waterways due to the fact that many national tourist, sailing, and kayak routes cross and meet here: Wielka Pętla Wielkopolska (688 km), Pętla Toruńska $(487 \mathrm{~km})$, Pętla Kujawska $(269 \mathrm{~km}) .{ }^{28}$ Along the River Vistula other routes are established: biking routes, black biking route prepared by the Association for the Lower Vistula Friends (Towarzystwo Przyjaciót Dolnej Wisty) and the Vistula Route (Szlak Wisty) coordinated by Urząd Marszałkowski Województwa Kujawsko-Pomorskiego. The last route is intended to run along the whole length of the Vistula River. On top of those there are additional walking paths adjacent to the lower Vistula River; however, these are usually shorter in distance.

For tourists travelling by land, discovering the river and its surroundings depends on the access to various means of crossing waterways. The studied region is characterised by 10 bridges, one of those atop the dam in Włocławek, and 4 ferries operating only in peak seasons. It must be stated that despite the obvious transportation function, ferries are mainly an attraction for tourists. Another issue worth mentioning is the distance between bridges, which is important from the perspective of a tourist. The average stretch between bridges in the lower course of the River Vistula amounts to $40 \mathrm{~km} \cdot{ }^{29}$

The spatial distribution of tourism infrastructure found in the riverside communes has been described on the basis of selected variables found in the Regional Data Bank (2013). Those variables include the number and quality of facilities supporting water tourism, accommodations, as well as data concerning the length of biking routes. Conducting the cluster analysis of both urban and rural communes the following facts have been observed:

- separate clusters are constituted by Gdańsk (accommodations, ferry, quay), Stegna commune (accommodations, ferry), Dobrzyń nad Wisła (port and sailing club),

- the last cluster encompasses the remaining cities and towns with developed accommodation access (Bydgoszcz, Toruń, Ciechocinek, and Grudziądz) and facilities catering for the needs of water tourists (Włocławek, Tczew, Ciechocinek) (Figure 1).

The analysis of the riverside rural communes, from the perspective of the development of tourism infrastructure, does not bare resemblance to the joint analysis of urban and rural locations. The investigation has been concluded with describing five clusters differentiated by characteristic features:

- cluster I - Stegna, usually regarded as a touristy commune, is the only to boast two ferries together with the largest number of waterfront facilities and accommodations,

- cluster II - constituted by the rural commune surrounding Włocławek as it possesses two quays,

${ }^{28}$ J. Owsiak, J. Sewerniak, Możliwości użytkowania turystycznego dróg wodnych w Polsce, Wyższa Pomorska Szkoła Turystyki i Hotelarstwa, Zeszyty Naukowe nr 2, Bydgoszcz 2002, p. 81; R. Zamyślewski, Bydgoski Węzeł Wodny. Album map dla wodniaków. Przewodnik po polskich drogach wodnych, Stowarzyszenie na rzecz Turystyki Aktywnej, Rekreacji i Wypoczynku „Szkoła Przygody”, Bydgoszcz 2012, p. 6.

${ }_{29}$ Strategia rozwoju - Wisła. Województwo Kujawsko-Pomorskie, Zarząd Województwa Kujawsko-Pomorskiego, Toruń, p. 2. 


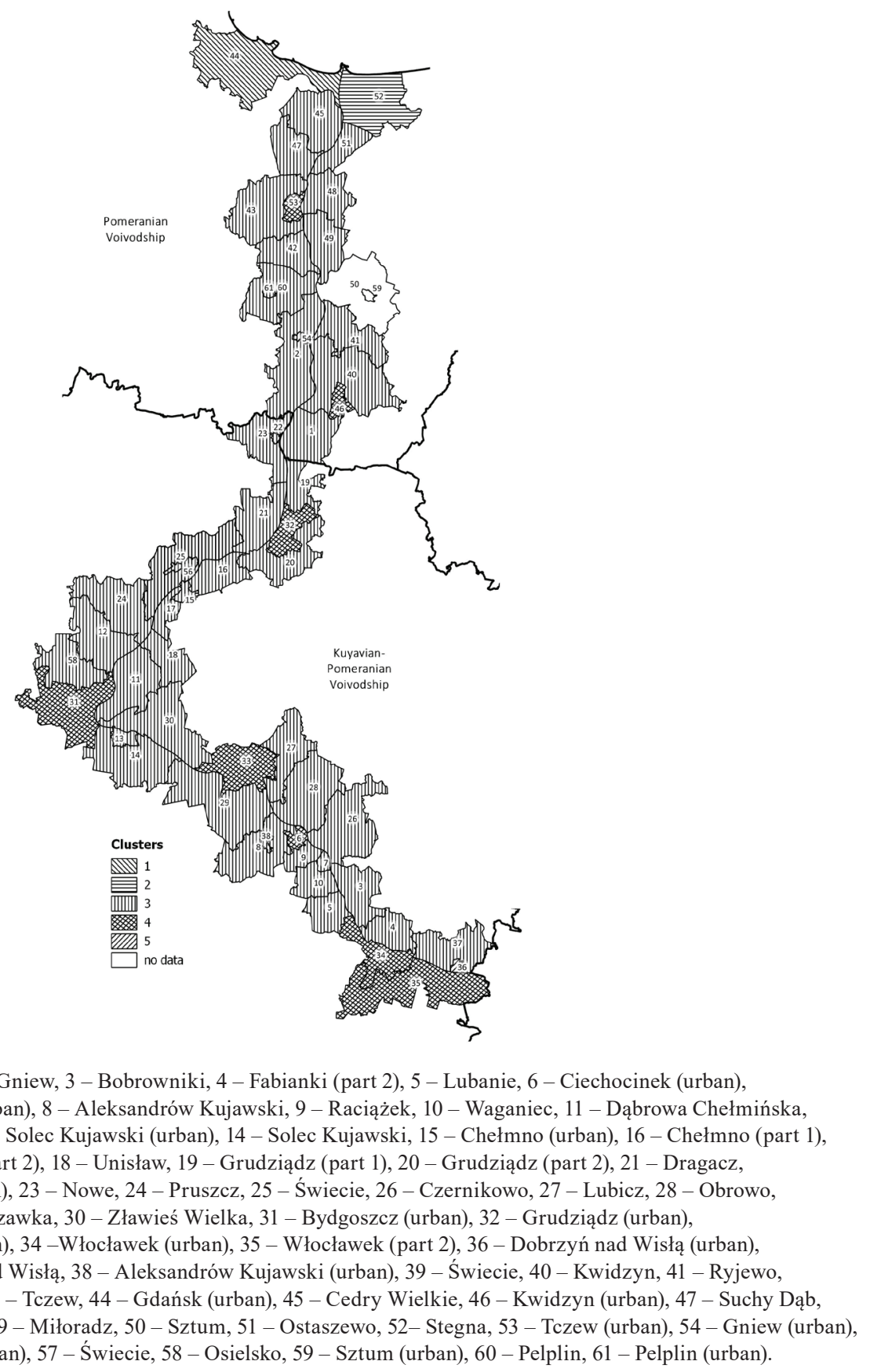

Figure 1. Similarities between riverside communes in the Kuyavia-Pomerania and the Pomerania Provinces in respect to development and arrangement of tourism infrastructure in 2013 (cluster analysis)

Source: the authors' analysis conducted on the basis of the data obtained from the Local Data Bank (2013). 
- cluster III - encompasses four rural communes connected to riverside towns: Chełmno, Dąbrowa Chełmińska, Lubicz neighbouring Toruń, and Raciążek, as these are characterised by a large number of biking routes amounting per $10,000 \mathrm{~km}^{2}$,

- cluster IV - groups 25 rural communes with underdeveloped tourism infrastructure

- cluster $\mathrm{V}$ - the last cluster caters for the communes with a higher number of accommodations, which at the same time surround the largest city of the region, Bydgoszcz (Dragacz, Osielsko, and Wielka Nieszawka communes), and smaller towns with interesting heritage, e.g., Tczew and Gniew.

As expected, the study has demonstrated a strong polarity between urban and rural riverside communes in terms of current tourism potential and also of the development of tourist facilities. Such a state is a direct result of socio-economic processes characterising investigated units: economic specific character, income, and expenditure on investments into developing tourism. Even though cities under scrutiny are described by indicators demonstrating readiness to develop tourism on the basis of Vistula River and its potential, it must be stated that a number of rural communes are embracing the idea of promoting and developing of various form of tourism, including water tourism.

\section{Features of tourism movement in the lower course of the River Vistula}

Rivers "are often positioned as an attraction, which contribute to the aesthetics of a destination and the quality of the tourism experience." ${ }^{30}$ However, in tourism, rivers are primarily utilised as waterways. The relation between tourism and rivers is much wider as it stretches beyond river banks. The development of tourism related to rivers must be perceived more holistically by linking rivers with their valleys into one coherent structure tourist-river. ${ }^{31}$ For this reason the volume of tourist traffic was calculated on the basis of numbers relating to rivers and also to their surroundings. Those figures can be established due to statistical data relating to lockages performed near the River Vistula. In relation to the studied area those locks are found on Nogat: Biała Góra, Szonowo, Rakowiec, and Michałowo. The number of tourists calculated from the number of shipped vessels in 2006 varied between 163 (Michałowo) and 215 (Biała Góra). The traffic in the case of each lock is quite similar, which may suggest that most vessels - mainly sailing boats carrying tourists - cover the whole distance of the waterway towards Zalew Wiślany (the Vistula Lagoon) or via Kanat Jagielloński (Jagiellonian Canal) to Elbląga and later towards Pojezierze Itawskie (the Lake District of Iława). ${ }^{32}$ A similar number of crafts is registered at the Bydgoszcz Canal, where up to 150 small vessels moor each season. ${ }^{33}$

${ }^{30}$ L. de Witt after Prideaux et al., 2009; Jones et al., 2006; Bogdanovitz \& Martinac, 2007, p. 3

31 R. Wiluś, Nadrzeczna przestrzeń turystyczna, ,Turyzm” 2007, nr 17/1-2, Wydawnictwo Uniwersytetu Łódzkiego, p. 133; R. Wiluś, Od szlaku wodnego..., p. 51.

32 R. Wasil, Rewitalizacja szlaków wodnych Delty Wisly i Zalewu Wiślanego, in: Rewitalizacja drogi wodnej Wisła-Odra szansą dla gospodarki regionu, t. I, Przyroda i turystyka regionu Pomorza i Kujaw, ed. Z. Babiński, Urząd Marszałkowski Województwa Kujawsko-Pomorskiego, Instytut Geografii UKW, Bydgoszcz 2008, p. 56.

${ }^{33}$ R. Zamyślewski, Bydgoski Węzet Wodny, Album map dla wodniaków. Przewodnik po polskich drogach wodnych, Stowarzyszenie na rzecz turystyki aktywnej, rekreacji i wypoczynku „Szkoła Przygody”, Bydgoszcz 2012. 
The waterways found at the delta of the River Vistula are quite satisfactory for water transportation, hence, the size of traffic is assessed at nearly 1,000 small crafts for tourists and nearly 500 vessels carrying goods and passengers. The data reflects the state of affairs in the first years of the 21 st century. ${ }^{34}$ However, a bulk of those crafts is constituted by yachts and motorboats transported from the Gdańsk Bay to Zalew Wiślany and towards Pojezierze Iławskie. As a result, there cannot be many tourists travelling towards E70 waterway in those numbers. Finally, at Bydgoszcz Canal the average lockage number for 2006 surpasses 1,400, and the lock found in Czersko Polskie has been used around 1,100 times. ${ }^{35}$ A constant growth of the traffic at Zalew Wiślany may have a positive impact on the amount of tourism movement on the River Vistula. This will come as a result of the programme devoted to "Economic Revitalization of the Delta of the Vistula River and of the Vistula Lagoon" (Programu rewitalizacji gospodarczej obszaru Delty Wisty i Zalewu Wiślanego) and its suplimentary project "Loop of the Vistula Delta - International Waterway E70" (Pętla Żuławska - Międzynarodowa Droga Wodna E70). In addition, the growing water tourism at the Gdańsk Bay may also translate into the increase in the volume of tourist movement on the Vistula River.

The towns and cities of the lower course of the Vistula River, just like rural areas in the vicinity, can boast significantly larger numbers of tourists. This view is supported by the data reflecting the usage of accommodations. Various places offering lodgings are visited by thousands (Nowe, Pelplin, Świecie, Wielka Nieszawka) or even hundreds of thousands visitors in towns and cities (Gdańsk, Toruń, Bydgoszcz, Ciechocinek), but even in rural communes the numbers grow from a dozen to a few thousand. However, twenty communes did not register a single usage of offered accommodations.

The analysis of types and forms of tourism in riverside locations requires taking into account both water tourism and land travels along rivers. ${ }^{36}$ Tourism qualities and development in the lower course of the River Vistula make sightseeing of primary importance as tourists flock to major cities and towns of the region. Even though these are located near the River Vistula, usually excursions are not related to the river itself. Culture tourism is also developing in the lower Vistula region, this time on the basis of: not so popular military facilities, e.g., the fortifications around Chełmno; ${ }^{37}$ qualities of waterside infrastructure; industrial monuments, e.g., the Bydgoszcz Canal together with the unused Old Bydgoszcz Canal, lock in Białą Góra, the historic bridges in Bydgoszcz and Grudziądz, and the long span lattice-truss bridge in Tczew considered by the American Society of Civil Engineers as a monument of heritage matching that of the Eiffel Tower or the Suez Canal. Another interesting location found at Żulawy is known as Little Holland due to the highest density

${ }^{34}$ R. Wasil, Rewitalizacja szlaków wodnych..., p. 55.

${ }_{35}$ M. Gorączko, Natężenie ruchu żeglugowego na bydgoskim odcinku drogi wodnej E-70-stan obecny i perspektywy rozwoju, in: Rewitalizacja drogi wodnej..., p. 30.

${ }^{36}$ R. Wiluś, Od szlaku wodnego..., p. 51.

${ }^{37}$ R. Gonia, T. Budzyński, Twierdza Chetmno. Przewodnik turystyczny, Towarzystwo Przyjaciół Dolnej Wisły, Świecie 2012. 
of waterways network with unique technical and hydrological monuments. This region is second depression located in a river delta surpassed only by the River Rhine. ${ }^{38}$

An even dispersion of major urban centres along the River Vistula is characteristic for KujawyPomerania Province. There are both the important centres such as Bydgoszcz, Toruń, Grudziądz, Włocławek, Chełmno, Świecie, Nowe, and Ciechocinek, as well as smaller but significant from the perspective of tourism towns of Tczew, Kwidzyn, Gniew, and Pelplin. This enables the development of the cultural product based on the tourism potential of all those locations with the River Vistula functioning as an axis joining them together, e.g., by providing guided cruises along the river, with sightseeing tours in urban and rural areas, where cultural and natural resources can be appreciated. ${ }^{39}$

Another feature growing in popularity are festivals promoting tourism qualities of the River Vistula and riverside locations, e.g., Ster na Bydgoszcz - the largest water festival in Europe; numerous Vistula festivals, e.g., Obchody Pomorskiego Święta Wisty held at the Tczew, Kwidzyń, and Sztum communes; sports events concentrating around rowing boats, e.g., Wielka Wioślarska o Puchar Brdy or men's eight regattas, both organised in Bydgoszcz.

On top of those events, specialised tourism is represented by biking as travellers are provided with long-distance and well-marked routes running along the River Vistula. In addition extreme sports gain in importance, e.g., paragliding at Starogród nad Wisłą. In this respect water tourism still seems underdeveloped. It is lacking in the low class of waterways, average water quality, insufficient amount of waterways designed for tourists, missing facilities designed specifically for water tourists, e.g., marinas, accommodations, access to restaurants, etc. It seems that the negative stereotype of the river has a strong impact on the situation, as the Vistula is often perceived as dirty, uninteresting, and dangerous. As mentioned before, the majority of Polish waterways can be accessed only by small vessels; hence, domestic inland water transport accounts barely for $0.7 \%$ of the total goods transport in the country ${ }^{40}$ and even less in relation to passenger. ${ }^{41}$

Sailing and kayaking, as forms of tourism, are also far from benefiting from the potential provided by the river. Floating down the whole length of the Vistula is still considered as a considerable achievement. The situation is slightly better in terms of transporting passengers; however, it is still far from satisfactory even though the slow process of the development must be attributed to both state and private initiatives. Taking care of passengers is most prominent in urban areas and in the delta of the River Vistula. Among the available options one can list: cruises in Bydgoszcz, e.g., aboard the only European solar water-tram Słonecznik (Sunflower) carrying above 40,000 passengers every year; ${ }^{42}$ cruises on a historic water-tram called Bydgoszcz; cruises up the river aboard Wanda and Wiking in Toruń, and ferry crossings on a motorboat known as Katarzynka (a name of a gingerbread type traditionally produced in Toruń); and other cruises near Ciechocinek or on Włocławek Reservoir.

\footnotetext{
${ }^{38}$ M. Kamiński, Wisła 1047 tajemnic, Fundacja Marka Kamińskiego, Gdańsk 2010.

39 According to J.M. Zaninetti (2014, p. 20), even the "river itself can be turned into a tourist attraction."

40 T. Jarzębińska, op.cit., p. 15.

${ }^{41}$ M. Gorączko, Natężenie ruchu żeglugowego..., p. 28.

42 www.tramwajwodny.byd.pl (15.09.2014).
} 
The long-distance journeys on the river are scarce to say the least. ${ }^{43}$ Fortunately, some Polish companies have started chartering boats on European waters, e.g., Holland, Germany, France, Italy, Ireland, Belgium, England, and Scotland, and finally in Poland as well. Still, the bulk of Polish water trips is confined to the waterways of the Mazury Lakes, the River Oder, the Gliwice Canal, the Augustów Canal, the Elbląg Canal, and then Pętla Żułąska, even though it is possible to rent boats for trips in the lower course of the River Vistula between Bydgoszcz and Torun or even up North to Żuawy. ${ }^{44}$ In terms of specialised tourism, it is worth mentioning kayaking trips within the Bydgoszcz-Torun Metropolitan Area or the two-week long International Kayaking Rally DrwęcaWisła which became one of the largest European events of the sort. The whole journey takes tourists on a voyage from Brodnica, via Golub-Dobrzyń, Toruń, Bydgoszcz, till they reach Chełmno. ${ }^{45}$ The promotion of water tourism is supported by the various badges such as Szlak Wisty $941.3 \mathrm{~km}$ (the Vistula Trail) established in 2009 by Centrum Turystyki Wodnej (the Water Tourism Centre), a division of Polskie Towarzystwo Turystyczno-Krajoznawcze (the Polish Tourist and Sightseeing Society). The aims of the badge can be enumerated as the promotion of: the qualities of the River Vistula, water tourism, and familiarising tourists with the infrastructure and facilities found along the river. ${ }^{46}$

It is also more common to see the development of barging, which is quite common in the West European countries such as e.g. Germany and Holland. In Poland it is better known as barking, and it simply refers to travelling by barges or various house-boats down rivers, canals, and lakes. ${ }^{47} \mathrm{In}$ terms of safety, this seems to be an optimum manner of travelling on the River Vistula especially when families with children are taken into consideration. It can also be perceived as an interesting alternative to yachting, which requires certificates and significant experience when sailing on a river of such a magnitude as the Vistula. In comparison, the revised legislation allows barging without certificates. Advantages of barging are numerous ranging from comfort and safety, which is the result of a slow pace of travelling. Barging has already influenced water tourism in Poland as the number of mooring locations has increased, and this enables sightseeing of the neighbourhood.

The recreational tourism in the vicinity of the lower course of the River Vistula is mostly present around the Włocławek Reservoir and in the commune of Stegna. The systematic growth of water quality in the River Vistula, especially from the border of the Mazovia Province to Toruń, ${ }^{48}$ should have a positive influence on the development of recreational tourism along the whole stretch of the lower course of the river. In addition to everything mentioned so far, angling is also growing in popularity, especially at the Włocławek Reservoir. It is also possible to recall here the long

43 Though „cruises are constantly increasing worldwide and represent an attractive form of contemporary tourist travel". N. Vuksanović, T. Pivac, A. Dragin, Contemporary Trends in Nautical Tourism on the Example of European River Cruising Companies, Researches Reviews of the Department of Geography, Tourism and Hotel Management, 2013, No. 42 , p. 124.

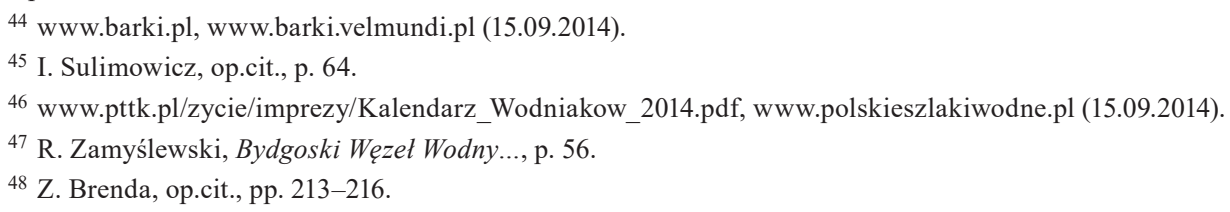


traditions of spa tourism, e.g., in Chiechocinek located near the Vistula River. As data analysis suggests, this town may function as an important pivot in generating tourism movement towards other riverside regions.

Summarising the above mentioned arguments relating to the size, type, and forms of tourism movements at the lower course of the Vistula River, it becomes possible to distinguish main tourist centres, namely the cities. In this case we must speak about educational tourism, which usually has no connection to the river. There are also some smaller local centres with a significant tourist traffic with well develop facilities. Tourists are drawn to those towns and communes mainly due to important monuments, e.g., Gniew with its Teutonic Knights' castle. Unfortunately, the Vistula Valley lacks small villages which would cater for tourists with basic tourist facilities like resorts, bungalows or campsites, and marinas.

\section{Conclusions}

The objective of this paper is to demonstrate the tourism potential of the communes located in the valley of the River Vistula while focusing on the possibility of grounding the development of water tourism on their example. Additionally, the authors have tried to demonstrate various revitalisation enterprises which aim at turning the river into a tourist hub. In the course of the analysis it has been discovered that the River Vistula is usually treated as an addition to other offers presented to tourists. It can be stated that tourism in the riverside communes does not relate directly to the river, but rather concentrates in towns and cities accidentally located at Vistula. Nowadays, the river is finally promoted as possessing an immense potential to be utilised in numerous manners. Finally, it is perceived as a significant factor in the development of tourism in riverside communes as well as the whole province.

This tourism potential is, however, extremely uneven at the whole studied span of the Vistula. To some extent such state can be explained by the specific arrangement of cities and towns versus small rural communes. Conducting the analysis has enabled reaching the conclusion that it is the largest centres together with a handful of more touristy communes, e.g., Stegna, Ciechocinek, and Gniew which dominate the whole region. It is those few locations that offer a diversified tourism product.

It has been postulated that the possibility of utilising the potential of riverside communes lies in the resourceful application of water transport on the basis of the international waterway E70. An asset which should be considered is the limited transport of goods on one hand, and the direct link to Western Europe via rivers and canals. Those two factors together may generate a substantial tourism movement.

Currently, the potential of the lower course of the River Vistula is mostly driven towards education tourism as well as active leisure, especially biking in rural areas. Revitalisation together with the promotion of the Vistula as the E70 waterway gradually develop into, mainly, the waterrelated tourism. This fact can help the communes unable to compete with the potential of other locations characterised by a high numbers of attractions. Through the process of revitalisation 
of waterways some communes can focus on the tourism movement and water tourism, e.g., by supporting tourist traffic, sailing or barging.

It cannot but be emphasized how important it is to raise the awareness of local inhabitants about the potential provided by the river, and how this potential can be utilised. Local and regional authorities must be included in that perspective. ${ }^{49}$ The cooperation between the authorities of riverside communes has already been functioning. The declaration of mutual action signed by the Chief Executives from six provinces establishes the grounds for a far-reaching collaboration in respect of developing goods and tourist transport of the whole E70 waterway while retaining its core natural qualities. ${ }^{50}$ Undoubtedly such an approach may have a strong impact on the socioeconomic development of the regions located in the vicinity of the waterway as the influx of tourists translates directly into higher incomes and increased employment.

When listing major obstacles, the class of waterways must be mentioned at the beginning of the list together with the insufficient development of facilities necessary of water tourism. In respect of active leisure on land, one must refer to the scarcity of various ways of crossing rivers. In addition the majority of offered accommodations is located at cities and towns, away from rural areas of the riverside.

Eventually, the authors have stressed the fact that, due to the poor characteristics of the River Vistula seen as a waterway, and because of no perspectives of immediate development of water transportation system, the revitalisation of the River Vistula becomes of prime importance. It should be adapted to the needs of tourism movement. In the lower course of the river it is barely possible to see a coherent tourism product offered in relation to the Vistula. There is no integrated plan proposing a comprehensive utilisation of the river in a wider tourism perspective.

\section{References}

Angiel J., Rzeka Wisła, jej wartości i percepcja. Wisła w edukacji geograficznej, Uniwersytet Warszawski, Wydział Geografii i Studiów Regionalnych, Warszawa 2011.

BarrakudR.,Rivieresdufutur, wildrivers?,in:Fleuves, estuairesetcoursd'eau:représentationsetpratiques, eds.D.Féménias, O. Sirost, «VertigO», hors-série 10/Décembre, https://vertigo.revues.org/11411?lang=eng\#bibliography.

Bogdanowicz P., Martinac I., Determinants and Benchmarking of Resource Consumption in Hotels - Case Study of Hilton International and Scandic in Europe, "Energy and Buildings" 2014, No. 39, pp. 82-95.

Brenda Z. Dolna Wisła - droga wodna, obszar aktywizacji gospodarczej województwa kujawsko-pomorskiego, „Gospodarka Wodna” 2013, nr 6.

Całbecki P. Rzeki dla regionów - czy stać nas na projekty cywilizacyjne?, „Gospodarka Wodna” 2013, nr 6.

Czarnecki A., Luc M., Lewandowska-Czarnecka A., Waterway Contributions to Ecological European Tourism and Interregional Economy: Example of West-East Inland Route in Poland, "Journal of Agricultural, Food, and Environmental Sciences" 2007, Vol. 1, Issue 1, www.scientificjournals.org/journals2007/j_of_agri.htm.

Gonia R., Budzyński T., Twierdza Chełmno. Przewodnik turystyczny, Towarzystwo Przyjaciół Dolnej Wisły, Świecie 2012 .

49 In many European countries there function programmes which integrate local communities and local governments for the sustainable development of riverside areas - in Belgium - Contrat de Rivieres (http://environnement.wallonie.be/ contrat_riviere/contrats.htm), in France - Contrat de Milieu (www.gesteau.eaufrance.fr/presentation/contrat).

${ }^{50}$ www.mdwe70.pl (15.09.2014). 
Gorączko M. Natężenie ruchu żeglugowego na bydgoskim odcinku drogi wodnej E-70 - stan obecny i perspektywy rozwoju, in: Rewitalizacja drogi wodnej Wisła-Odra szansq dla gospodarki regionu, t. I, Przyroda i turystyka regionu Pomorza i Kujaw, ed. Z. Babiński, Urząd Marszałkowski Województwa Kujawsko-Pomorskiego, Instytut Geografii Uniwersytetu Kazimierza Wielkiego, Bydgoszcz 2008.

Hölzer Ch., Hundt T., Lüke C., Hamm O.G., Riverscapes Designing Urban Embankments, Birkhaüser Basel, Boston, Berlin 2010.

http://environnement.wallonie.be/contrat_riviere/contrats.htm.

Jarzębińska T., Rola polskich dróg wodnych śródlądowych w sieci europejskiej, in: Rewitalizacja drogi wodnej WisłaOdra szansa dla gospodarki regionu, t. I, Przyroda i turystyka regionu Pomorza i Kujaw, ed. Z. Babiński, Urząd Marszałkowski Województwa Kujawsko-Pomorskiego, Instytut Geografii Uniwersytetu Kazimierza Wielkiego, Bydgoszcz 2008.

Jones B.E., Scott D., Gössling S., Lakes and Streams, in: Tourism and Global Environmental Change: Ecological, Social, Economic and Political Interrelationships, eds. S. Gössling, M. Hall, Routledge, New York 2006, pp. 76-94.

Kaczmarek J., Stasiak A., Włodarczyk B., Produkt turystyczny, PWE, Warszawa 2005.

Kamiński M., Wisła 1047 tajemnic, Fundacja Marka Kamińskiego, Gdańsk 2010.

Kondracki J., Geografia Polski. Mezoregiony fizyczno-geograficzne, PWN, Warszawa 1994.

Kowalczyk A., Derek M., Zagospodarowanie turystyczne, PWN, Warszawa 2010.

Kurek Z. (ed), Turystyka, PWN, Warszawa 2007.

Leśniewski G. (ed), Wisła dzika rzeka, Lubelskie Towarzystwo Ornitologiczne, Wydawnictwo Epigraf, Warszawa 2012.

Liszewski, S. (ed), Możliwości i kierunki rozwoju turystyki w Dolinie Odry, Katedra Geografii Miast i Turyzmu, Łódzkie Towarzystwo Naukowe, Łódź 2003.

Łożewski W., Partnerstwo w rozwoju dróg wodnych. Miejsce żeglugi towarowej w planach rewitalizacji drogi wodnej Wista-Odra, in: Rewitalizacja drogi wodnej Wisła-Odra szansa dla gospodarki regionu, t. III, Przyroda i turystyka regionu Pomorza i Kujaw, ed. Z. Babiński, Urząd Marszałkowski Województwa Kujawsko-Pomorskiego, Instytut Geografii Uniwersytetu Kazimierza Wielkiego, Bydgoszcz 2009.

Owsiak J., Sewerniak J., Ekorozwój a turystyka na przykładzie dorzecza Drwęcy, in: Rola samorządu terytorialnego w kształtowaniu przestrzeni obszarów chronionych. Ekologia w turystyce, Materiały konferencyjne, Włocławskie Centrum Edukacji Ekologicznej, Włocławek 2001.

Owsiak J., Sewerniak J., Możliwości użytkowania turystycznego dróg wodnych w Polsce, Wyższa Pomorska Szkoła Turystyki i Hotelarstwa, Zeszyty Naukowe nr 2, Bydgoszcz 2002.

Prideaux B., Timothy D.J., Cooper M., Introducing River Tourism: Physical, Ecological and Human Aspects, in: River Tourism, eds. B. Prideaux, M. Cooper, Oxfordshire, Cabi 2014, pp. 1-22.

Rozkrut D., Żegluga śródlądowa w Polsce w latach 2006-2009, GUS Urząd Statystyczny w Szczecinie, Warszawa 2010, www.stat.gov.pl.

Strategia rozwoju - Wisła. Województwo Kujawsko-Pomorskie, Zarząd Województwa Kujawsko-Pomorskiego, Toruń.

Sulimowicz I., Wykorzystanie dolin rzecznych Bydgosko-Toruńskiego Obszaru Metropolitalnego dla potrzeb rozwoju turystyki i rekreacji, in: Warunki rozwoju turystyki w dolinach rzecznych, ed. M. Grabiszewski, Zeszyty Naukowe WSG, t. 15, nr 7, Wydawnictwo Uczelniane WSG, Bydgoszcz 2010.

Ustawa o żegludze śródlądowej z dnia 21 grudnia 2000 r., Dziennik Ustaw Rzeczypospolitej Polskiej z dnia 6 grudnia 2013 r. poz. 1458, Obwieszczenie Marszałka Sejmu Rzeczypospolitej Polskiej z dnia 15 października 2013 r. w sprawie ogłoszenia jednolitego tekstu ustawy o żegludze śródlądowej.

Vuksanović N., Pivac T., Dragin A., Contemporary trends in nautical tourism on the example of European river cruising companies, Researches Reviews of the Department of Geography, Tourism and Hotel Management 2013, No. 42.

Warszyńska J., Jackowski A., Podstawy geografii turyzmu, PWN, Warszawa 1979.

Wasil R., Rewitalizacja szlaków wodnych Delty Wisły i Zalewu Wiślanego, in: Rewitalizacja drogi wodnej WisłaOdra szansa dla gospodarki regionu, t. I, Przyroda i turystyka regionu Pomorza i Kujaw, ed. Z. Babiński, Urząd Marszałkowski Województwa Kujawsko-Pomorskiego, Instytut Geografii Uniwersytetu Kazimierza Wielkiego, Bydgoszcz 2008.

Wiluś R., Nadrzeczna przestrzeń turystyczna, „Turyzm” 2007, nr 17, Wydawnictwo Uniwersytetu Łódzkiego. 
Wiluś R., Od szlaku wodnego do nadrzecznego regionu turystycznego - kilka uwag o roli rzeki w ksztaltowaniu regionu turystycznego, in: Rewitalizacja drogi wodnej Wista-Odra szansa dla gospodarki regionu, t. III, Przyroda i turystyka regionu Pomorza i Kujaw, ed. Z. Babiński, Urząd Marszałkowski Województwa Kujawsko-Pomorskiego, Instytut Geografii Uniwersytetu Kazimierza Wielkiego, Bydgoszcz 2009.

de Witt L. The Importance of an Eco-efficient Tourism Industry Surrounding the Vaal River: a Tourist's Perspective, "African Journal of Hospitality, Tourism and Leisure" 2014, Vol. 3, No. 2.

Vuksanović N., Pivac T., Dragin A., Contemporary Trends in Nautical Tourism on the Example of European River Cruising Companies, Researches Reviews of the Department of Geography, Tourism and Hotel Management, 2013, No. 42.

www.gesteau.eaufrance.fr/presentation/contrat.

www.stat.gov.pl/bdl.

www.barki.pl.

www.barki.velmundi.pl.

www.mdwe70.pl.

www.polskieszlakiwodne.pl.

www.pttk.pl/zycie/imprezy/Kalendarz_Wodniakow_2014.pdf.

www.tramwajwodny.byd.pl.

Zajadacz A., Potencjał miast na przykładzie wybranych miast Sudetów Zachodnich, Bogucki Wydawnictwo Naukowe, Poznań 2004.

Zajadacz A., Śniadek J., Ocena potencjału turystycznego, in: Uwarunkowania i plany rozwoju turystyki, t. III, Walory $i$ atrakcje turystyczne. Potencjat turystyczny. Plany rozwoju turystyki, eds. Z. Młynarczyk, A. Zajadacz, Wydawnictwo Naukowe UAM, Poznań 2009.

Zamyślewski R., Wisła. Album map dla wodniaków. Przewodnik po polskich drogach wodnych, Stowarzyszenie na rzecz turystyki aktywnej, rekreacji i wypoczynku „Szkoła Przygody”, Bydgoszcz 2011.

Zamyślewski R., Bydgoski Węzel Wodny. Album map dla wodniaków. Przewodnik po polskich drogach wodnych, Stowarzyszenie na rzecz turystyki aktywnej, rekreacji i wypoczynku „Szkoła Przygody”, Bydgoszcz 2012.

Zaninetti J.M., Where's the Great River Road?, “Geography and Tourism” 2014, Vol. 2, No. 1, Kazimierz Wielki University Press Bydgoszcz, 2014. 


\section{POTENCJAŁ TURYSTYCZNY GMIN NADWIŚLAŃSKICH \\ WOJEWÓDZTWA KUJAWSKO-POMORSKIEGO I POMORSKIEGO \\ W KONTEKŚCIE REWITALIZACJI DRÓG WODNYCH}

SŁOWA KLUCZOWE

STRESZCZENIE
Wisła, turystyka, Międzynarodowa Droga Wodna E70

Celem artykułu jest określenie potencjału turystycznego gmin nadwiślańskich jako czynnika aktywizacji społeczno-gospodarczej obszaru i zbadanie wpływu rewitalizacji Wisły na rozwój turystyki, w tym poprawę możliwości turystycznego użytkowania rzeki. Jako obszar badawczy przyjęto gminy i miasta położone bezpośrednio nad dolną Wisłą w obrębie województwa kujawsko-pomorskiego i pomorskiego. W artykule założono, iż obszar dolnej Wisły posiada niezbędny potencjał (naturalny i kulturowy) do rozwoju różnych rodzajów i form turystyki. Rozwój ten uwarunkowany jest stanem zagospodarowania turystycznego oraz sytuacją społeczno-ekonomiczną gmin (zwłaszcza w zakresie ponoszonych wydatków na turystykę). Ważnym czynnikiem wspierającym rozwój turystyki jest realizacja ogólnej koncepcji zrewitalizowania odcinka dolnej Wisły, jako fragmentu w szczególności Międzynarodowej Drogi Wodnej E70. W celu wychwycenia podobieństwa w potencjale turystycznym gmin badanego obszaru zastosowano analizę wielozmienną w postaci analizy skupień metodą k-średnich, wyliczono również odległości euklidesowe dla każdej jednostki administracyjnej, po uprzednim zestandaryzowaniu danych. 